\title{
Suboccipital Lateral Injection of Intrathecal Chemotherapy in a Patient with Mantle Cell Lymphoma
}

\author{
S. Pachmann ${ }^{\mathrm{a}}$ \\ R. Bruning ${ }^{b}$ \\ M. Schaffera \\ E. Dühmke \\ a Department of Radiation Therapy and Radiation Oncology, \\ ${ }^{\mathrm{b}}$ Department of Radiology, Munich University, Germany
}

Key Words

Mantle cell lymphoma - Suboccipital puncture . Cerebrospinal fluid

\section{Summary}

Background: Even today patients who suffer from mantle cell lymphoma have a poor prognosis, especially when the CNS is involved. To confirm the diagnosis of meningeosis lymphomatosa, asservation of the liquor cerebrospinalis is necessary. During this procedure, intrathecal chemotherapy may be given if there is clinical evidence of meningeosis. If lumbar puncture cannot be performed, a lateral suboccipital puncture may be an alternative approach. Patient and Methods: We report the case of a 65-year-old patient who suffered from mantle cell lymphoma stage IV. The patient presented with symptoms of progressive paraparesis of both legs and incontinence, with tumor mass intradural from the 12th thoracic vertebra to the level of S1. During irradiation, the patient developed symptoms of diffuse meningiosis lymphomatosa. The conventional lumbar puncture was impossible, because of tumor present in the thoracico-lumbar junction. Results: A suboccipital puncture was performed for both collecting cerebrospinal fluid and application of chemotherapy (cytosine arabinoside/dexamethasone). This lead to remarkable improvement of the patient's clinical symptoms. Conclusion: The suboccipital cervical puncture was performed without complications. A variation of the intrathecal approach is described, which may serve as alternative when conventional lumbar puncture is not possible.
Schlüsselwörter

Mantelzellymphom · Subokzipitalpunktion · Liquor

\section{Zusammenfassung}

Hintergrund: Patienten mit Mantelzellymphomen haben auch heute eine schlechte Prognose, insbesondere bei Befall des ZNS. Um eine bestehende Meningeosis lymphomatosa zu sichern ist die Gewinnung von Liquor notwendig, wobei bei klinischer Evidenz unmittelbar anschließend eine intrathekale Therapie verabreicht werden kann. Ist dies durch Lumbalpunktion z. B. aufgrund eines lumbalen Befalles nicht möglich, so kann alternativ der Zugang über eine laterale subokzipitale Punktion gewählt werden. Patient und Methoden: Wir berichten über einen 65 Jahre alten Patienten mit Mantelzellymphom Stadium IV, der mit einer progredienten Paraparese beider Beine sowie Harn- und Stuhlinkontinenz bei intraduralen Tumormassen von BWK 12 bis SWK 1 ins Krankenhaus eingewiesen wurde. Während der Bestrahlung im Wirbelsäulenbereich entwickelte der Patient Symptome einer diffusen Meningeosis lymphomatosa. Eine konventionelle Lumbalpunktion erschien aufgrund des intraduralen Tumors im Bereich der LWS nicht durchführbar. Ergebnisse: Diagnostik und Therapie wurden über eine direkte subokzipitale Punktion durchgeführt, bei der Liquor gewonnen und anschließend eine intrathekale Chemotherapie (Cytosinarabinosid/Dexamethason) verabreicht wurde. Daraufhin besserte sich der klinische Zustand des Patienten rasch. Schlussfolgerung: Die laterale subokzipitale Liquorpunktion und Instillation von Chemotherapie erwies sich in diesem Fall, in dem eine lumbale Liquorpunktion nicht möglich war, als komplikationslos und erfolgreich durchführbar und kann in ähnlichen Fällen als Alternative dienen.

\begin{tabular}{ll}
\hline KARGER & @ 2004 S. Karger GmbH, Freiburg \\
Fax +49761 4520714 & Accessible online at: \\
$\begin{array}{l}\text { E-mail Information@Karger.de } \\
\text { www.karger.com }\end{array}$ & www.karger.com/onk \\
&
\end{tabular}




\section{Introduction}

Mantle cell lymphoma (MCL) is a subtype of non-Hodgin's lymphoma (NHL) that often presents in advanced stages with systemic spread [1]. Spinal involvement is uncommon and generally occurs as part of advanced disease or generalized relapses. Primary spinal epidural lymphoma is a rare initial manifestation, and mantle cell lymphoma with initial presentation in the spinal epidural space is extremely rare [1]. MCL is considered a distinct disease entity within the heterogenous group of NHL, although the cytology and growth pattern of MCL can be quite variable and the clinical significance of these features is unclear.

MCL was classified in the past (Kiel classification) as centrocytic lymphoma [2], lymphocytic lymphoma of intermediate differentiation (1974) and mantle cell lymphoma (1982); in the working formulation it was considered as either small lymphocytic lymphoma, follicular small cleaved cell lymphoma, or diffuse large cleaved cell lymphoma [3]. Specific diagnostic criteria, based on morphologic, cytogenetic and immunophenotypic features, have been proposed in REAL and WHO classifications (in 1994 and 1999, respectively), which suggested that MCL should be regarded as a specific entity.

MCL cells are derived from the follicle mantle of lymph nodes, physiologically representing $2-5 \%$ of normal B cells in adult lymph nodes and tonsils. A characteristic cytogenetic abnormality, the $\mathrm{t}(11 ; 14)(\mathrm{q} 13 ; \mathrm{q} 32)$ can be detected in about $75 \%$ of patients [2]. A deleted segment of 11q22-q23 bands affecting the ATM (ataxia-teleangiectasia mutated) gene in $50 \%$ of MCL has recently been identified; extinction of ATM function might be the first event leading to malignant transformation of cells of the follicular mantle. Other abnormalities such as p53 mutations, inactivation of the CDKN2/p16 gene or overexpression of the c-myc gene are observed in $5-38 \%$ of the patients and usually associated with unfavorable prognosis [3].

The incidence of MCL is 3 in 100,000 residents [4]. In Europe, $7-9 \%$ of the patients with NHL suffer from MCL [5]. There is a predominance of male patients with a male/female ratio $>6$. B symptoms are reported in $25-50 \%$ of the patients; multiple gastrointestinal involvement is reported in $15-40 \%$ and bone marrow infiltration is detected in $60 \%$.

About $80-90 \%$ of newly diagnosed patients are stage III-IV according to the Ann Arbor classification [3]. MCL has a poor prognosis; median survival time is 3-4 years. Main prognostic criteria are presence of large blastoid cells, age $>60$ years, stage II-IV, elevated LDH level and circulating lymphoma cells.

The diagnosis of MCL, especially of high grade variants, is particularly challenging, as these tumors exhibit a broad spectrum of morphologic findings that can be misinterpreted as other types of NHL [5]. Histologic review includes study of the morphological appearance of the cells and architectural pattern, immunohistochemical analysis using the monoclonal antibodies CD3, CD5, CD10, CD19, CD20, CD23, heavy- and light-chain immunoglobulins and description of cytogenetic abnormalities according to the International System for Human Cytogenetic Nomenclature [3].

The treatment of MCL depends on the tumor stage. Stage I-II are treated with radiation therapy with $26-40$ Gy [2]. Stage III-IV are treated with various chemotherapy regimens; studies showed better response rates of anthracyclin-based regimens, however, without any impact on the natural history of the disease and on survival compared to other chemotherapy regimens. Other substances, such as fludarabin, paclitaxel, and gemcitabine have been tested with response rates between 14 and $33 \%$. Combinations of 2CDA (2-chlordeoxyadenosine) and mitoxantrone achieved 3\% complete remissions and $100 \%$ responses, the median duration of response varied between 18 and 24 months [3].

High-dose chemotherapy in combination with autologous stem cell transplantation is being investigated. Complete remission rates varied between 44 and $100 \%$ in various non-randomized studies; despite improved median survival most studies showed no evidence for long-term remission [3].

The effect of monoclonal anti-CD20 antibody (rituximab) is now being evaluated in various studies. Recent approaches have tested in vivo purging of blood and bone marrow with rituximab and subsequent stem cell transplantation with encouraging results so far (26/28 patients disease-free after a median follow-up of 22 months; 2 patients died) [6].

Involvement of the central nervous system is a rare complication in patients with mantle cell lymphoma. Oinonen et al. [7] retrospectively analyzed 94 patients with histologically confirmed MCL and found CNS involvement in 4 patients (4\%). CNS involvement occurred 4.6-86 months after first diagnosis. All patients had neurological symptoms and leukemic disease; in 2 cases blastoid transformation was suspected. Malignant cells were detected in the cerebrospinal fluid in all cases, parenchymal infiltrations in the brain were seen in 2 cases. All patients were treated with intrathecal chemotherapy without response; survival time after diagnosis ranged from 18 to 55 days. Another study of Valdez et al. [8] reviewed the medical records of 108 patients with MCL for CNS involvement; the overall rate of positive cytologic findings in the cerebrospinal fluid being $9 \%$.

The diagnosis of meningeal manifestations can be based on clinical symptoms, lumbar puncture and magnetic resonance imaging (MRI). With the aid of MRI, it has been possible to obtain direct images of neoplastic meningeosis [9]. However, the microscopic analysis of cells in the cerebrospinal fluid still remains essential.

We here report the case of a patient with pseudoobstruction of the spinal channel due to an intradural mass. Therefore, the classical way of performing a lumbar puncture was not advisable. In his case, also meningeal enhancement detected by cranial MRI indicated that an external ventricular drainage would not be sufficient. 


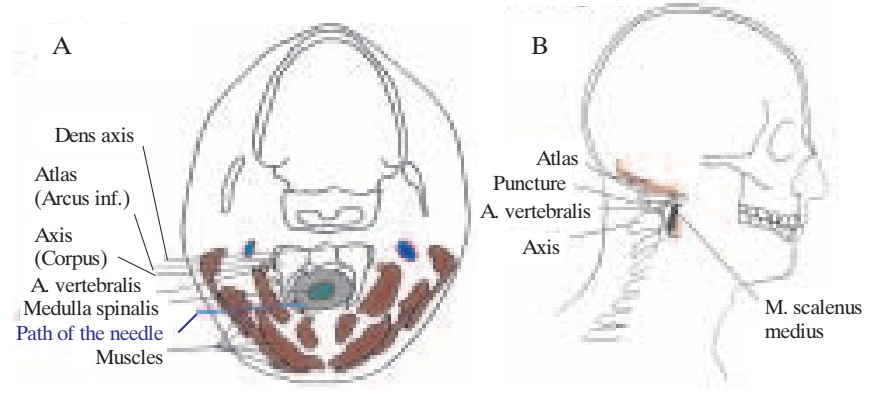

Fig. 1. Schematic representation of the suboccipital puncture procedure. A) Transverse section. B) Sagittal section.

The diagnostic/therapeutic procedures in those cases are limited to suboccipital puncture. Originally there were numerous diagnostic, therapeutic and scientific indications for suboccipital puncture. Most of them are out of date [10]. Still, it is a practicable alternative when lumbar puncture is impossible. The application of the suboccipital puncture procedure for injection of intrathecal chemotherapy will be described in this case report.

\section{Patient and Methods}

The patient was a 65-year-old male who suffered from stage IV MCL since July 2000. Mainly involved organs were the small bowel and ileum. He initially presented with symptoms of acute abdomen. Partial small bowel resection was performed. The histologic findings showed infiltration by MCL. Between August and December 2000, he was treated with 6 cycles of COP (cyclophosphamide, vincristine, and prednisone) chemotherapy, with partial remission. From January till May 2001, he was given 8 cycles of $\mathrm{CHOP}(\mathrm{COP}+$ adriamycin) with complete remission, confirmed by computer tomography scanning.

At the end of July 2001, acute progressive paraparesis of both legs and incontinence occurred. MRI showed intradural tumor masses from the 12th thoracic vertebra to the level of S1. Further manifestations of the disease were massive intra-abdominal bulk and lymphadenopathy in the right axillary region as well as in the region of hilus and the carina. Biopsy of the axillary lymph nodes confirmed the recurrence of anaplastic MCL. In this palliative situation with quick progression of symptoms we decided to proceed with irradiation of the spinal cord from TH11 to S1, with the aim of reducing the tumor mass in this region to try to avoid irreversible paraparesis and incontinence. The irradiation was performed using a $6 \mathrm{MV}$ linear accelerator, with application of $20.0 \mathrm{~Gy}$ (2.0 Gy per session). Initially the patient showed significant improvement of the neurological symptoms.

After 10 days of treatment the patient reported headache. He was partially desoriented with respect to time and place. Physical examinations showed nuchal hardness and partial blindness and deafness. MRI confirmed the suspected meningeosis lymphomatosa.

A conventional lumbar puncture was not performed because of the tumor being present in Th12-S1. We decided to proceed with suboccipital puncture to achieve two simultanous aims: diagnostic (tumor cells in the cerebrospinal fluid above the level of the obstruction) and therapeutic approach by giving intrathecal chemotherapy (cytosine arabinoside (Ara-C) and dexamethasone).

For suboccipital puncture procedure, the patient was positioned with extended neck in prone position on a fluoroscopic x-ray device. Guided by strict lateral fluoroscopic x-ray-beam a long $21 \mathrm{G}$ needle was inserted under sterile conditions and under local (lateral) anesthesia. After lateral puncture of the skin just caudal the ear, the needle was aimed at the line between the anterior surface of the dorsal arches of $\mathrm{C} 1$ and $\mathrm{C} 2$ and under strict fluoroscopic control advanced to the midline. When the needle tip was advanced, the beam of fluoroscopy was altered from lateral to anterior-posterior and vice versa, as the lateral view best controls the direction of the needle advancement and the anterior-posterior view enables to monitor the advancement of the needle tip to the midline. Following this approach, the needle reached the cisterna cerebro-medullaris. The flow of clear spinal fluid indicated a correct position, which was verified by $\mathrm{x}$-ray and contrast injection (fig. 1).

\section{Results}

The suboccipital puncture procedure was performed without complications. The obtained cerebrospinal fluid contained 2944/3 cells (identified as lymphoma cells) and few red blood cells. Also the intrathecal injection of $40 \mathrm{mg}$ Ara-C and $8 \mathrm{mg}$ Dexamethasone proceeded without any complications. Under this regimen, the patient showed improvement of the clinical symptoms, especially improvement of orientation, headache and partial recovery of blindness and loss of hearing within a few hours.

The diagnostic confirmation lead us to implant an Ommaya reservoir for further intrathecal chemotherapy [11]. This lead to a partial remission with no remarkable side effects. After two weeks, the patient received systemic chemotherapy. He died a few days later because of systemic organ failure, possibly due to infection during neutropenia.

\section{Conclusions}

We here described an alternative approach for spinal injection of chemotherapeutic agents in a patient with epidural masses caused by mantle-cell lymphoma. Due to the localization of these masses a lumbar approach was not possible in this patient. Thus, we decided to perform a suboccipital puncture.

The suboccipital puncture today is a rare procedure [10], still it is a practicable alternative when lumbar puncture is impossible. The lateral cervical suboccipital puncture offers an alternative for diagnostic and therapeutic approaches. The extracranial part of the cisterna magna cerebellomedullaris provides enough space to ensure the definite position of the needle without any major risk after puncture through the atlanto-occipital membrane. Complications of this approach can include problems related to the hyperextension of the cervical spinal canal, so care should be taken to exclude patients with a narrow spinal canal [12]. We did not observe, as reported in the past $[13,14]$, side effects such as pharyngeal pain or Lhermitte's sign. Other rare complications include puncture of the vertebral arteries [15]. Alternatively, an intrathecal administration of chemotherapeutic agents can also be per- 
formed by an external ventricular drainage through an Ommaya reservoir [11]. Positioning of the needle tip is possible under simple $\mathrm{x}$-ray control. Injury of the spinal cord is most unlikely to occur.

Pharmacokinetic studies have indicated that a potentially effective concentration of Ara-C is reached in cerebrospinal fluid during and after high-dose infusions of the drug given in- travenously. The proven effectivity of intrathecal treatment in patients with meningeosis lymphomatosa $[16,17]$ lead us to use these agents. Methotrexate (MTX) can also be used for intrathecal treatment [18].

The partial remission achieved in this patient confirms the feasibility of this approach in rare cases like the case reported here.

\section{References}

1 Barnard M, Perez-Ordonez B, Rowed DW, Ang LC: Primary spinal epidural mantle cell lymphoma: Case report. Neurosurgery 2000;47:1239-1241.

2 Pötscher $\mathrm{CH}$, Hiller E, Busch M, Unterhalt M, Hiddemann W: Follikuläre Lymphome, MantelzellLymphome und Marginalzonen-Lymphome; in Emmerich B (Hrsg): Maligne Lymphome. Tumorzentrum München. München, Zuckschwerdt, 2000, pp 76-94.

3 Decaudin D: Mantle cell lymphoma: A biological and therapeutic paradigm. Leuk Lymphoma 2002; 43:773-781

4 Hiddemann W, Unterhalt M, Sack H: Current status of therapy of follicular germ center lymphoma and mantle cell lymphoma. Internist (Berl) 1997;38: 122-134

5 Meusers P, Hense J, Brittinger G: Mantle cell lymphoma: Diagnostic criteria, clinical aspects and therapeutic problems. Leukemia 1997;11(Suppl 2): S60-S64.

6 Gianni AM, Cortelazzo S, Magni M, Martelli M: Rituximab: Enhancing stem cell transplantation in mantle cell lymphoma. Bone Marrow Transplant 2002;29(Suppl 1):S10-S13.
7 Oinonen R, Franssila K, Elonen E: Central nervous system involvement in patients with mantle cell lymphoma. Ann Hematol 1999;78:145-149.

8 Valdez R, Kroft SH, Ross CW, Schnitzer B, Singleton TP, Peterson LC, Finn WG: Cerebrospinal fluid involvement in mantle cell lymphoma. Mod Pathol 2002;15:1073-1079.

9 Schumacher M, Orszagh M: Imaging techniques in neoplastic meningiosis. J Neurooncol 1998;38:111120

10 Loebe FM: History and significance of suboccipital puncture. Psychiatr Neurol Med Psychol (Leipz) 1988;40:617-620.

11 Berweiler U, Krone A, Tonn JC: Reservoir systems for intraventricular chemotherapy. J Neurooncol 1998;38:141-143.

12 Robertson HJ, Smith RD: Cervical myelography: Survey of modes of practice and major complications. Radiology 1990;177:590-591.

13 Rossitti SL, Araujo JF, Zuiani AR, Balbo RJ: Pharyngeal pain during suboccipital puncture. Arq Neuropsiquiatr 1989;47:182-186.
14 Rossitti SL, Balbo RJ: Lhermitte's sign during lateral cervical puncture: Survey of possible accidents in the lateral $\mathrm{C} 1-\mathrm{C} 2$ puncture and report of 2 cases of spinal cord penetration. Arq Neuropsiquiatr 1990;48:341-347.

15 Katoh Y, Itoh T, Tsuji H, Matsui H, Hirano N, Kitagawa $\mathrm{H}$ : Complications of lateral $\mathrm{C} 1-2$ puncture myelography. Spine 1990;15:1085-1087.

16 Nowrousian MR, Seeber S, Miller AA, Anders C, Ohl S, Schmidt CG: High-dose cytarabine treatment in acute leukemic meningiosis: Clinical aspects and pharmacokinetics. Onkologie 1985;8:2632.

17 Heider A, Engels B, Hartmann-Klosterkotter U, Kress M, Niederle N: Hypersalivation as a leading symptom of neoplastic meningeosis in highly malignant non Hodgin's lymphoma. Dtsch Med Wochensch 1993.12;118:19-22.

18 Zippel RM, Sack H: Side effects and late results of the combined radio- and chemotherapy of the brain in children with acute lymphoblastic leukemia. Strahlentherapie 1979;155:165-170. 